\begin{tabular}{ll}
\hline 臨 & 床 \\
\hline
\end{tabular}

\title{
耳硬化症の人工内耳症例に生じた顔面痤攣
}

\author{
平海 晴一1) ・高橋 晴雄 2$) \cdot$ 内藤 泰2) •三浦 誠 ${ }^{3)}$
}

\section{Facial Nerve Stimulation after Cochlear Implantation in a Patient with Otosclerosis}

\author{
Harukazu Hiraumi \\ (Amagasaki Prefectural Hospital) \\ Haruo Takahashi and Yasushi Naito \\ (Kyoto University) \\ Makoto Miura \\ (Hamamatsu Rosai Hospital)
}

\begin{abstract}
A 57-year-old woman with otosclerosis suffered from facial nerve stimulation after 3 years of successful use of a cochlear implant. Lateral X-rays revealed that all electrodes were placed in the proper position in the cochlea, with electrode arrays that were supposed to stimulate the facial nerve located in the posterosuperior portion of the basal turn. The cause of the facial spasm was attributed to otosclerosis and an osteolytic change in the ottic capsule between the responsible electrode arrays and the labyrinthine portion of the facial nerve.

With deprogramming of these electrodes, the facial nerve stimulation was eliminated without impairment of vowel discrimination.
\end{abstract}

Key words : facial nerve stimulation, cochlear implant, otosclerosis

はじめに

人工内耳埋め込み術後の合併症の 1 つとしての音刺激 による顔面痤攣は, 1988年のCohen ら 11 の報告が最初 であり，その後いくつかの報告が認められるが2) 4), Muckle $5^{2)}$ は耳硬化症の患者で人工内耳埋め込及術後 に高率に顔面痤攣が生じると報告した.

われわれは耳硬化症を伴ら患者に人工内耳埋め込久術 を施行して 3 年後に, 音刺激に反応して顔面痤攣をきた した 1 例を経験したので，文献的考察を加えて報告する.

\section{症例}

患者 : 57歳, 女性.

主訴 : 両側高度難聴.

既往歴, 家族歴 : 特記すべきことなし.

現病歴：45歳頃より徐々に聴力低下を自覚し，50歳頃 に両側襲となる. その後, 人工内耳埋め込々術を希望し て当科を受診した。

検查所見: 純音聴力検查では気導, 骨導とも両側ス ケールアウトで, ABR でも反応は認められなかった. 補聴器装用によっても音感を得られなかった。CT,

1）兵庫県立尼崎病院耳鼻咽喉科

2) 京都大学大学院医学研究科 感覚運動系病態学講座 聴覚・言語病態学領域

3）浜松労災病院耳鼻咽喉科 
MRI で内耳道に異常を認めず蝸牛内にも電極を挿入す る十分な空間を認めた．CT で悶側の前庭空の前方に骨 吸収像を認め5)，耳硬化症の存在を疑わせたが，ダブル リングサインなどの広範な蝸牛病変は認められず感音性 難聴の原因とは断定できなかった。54歳で左耳にコクレ ア社製22チャンネル人工内耳埋め込多術を施行した。術 中左耳の正円空は狭小化していたが，アクティブ電極は 全て蝛牛内に插入された。顔面神経は乳突部で一部露出 しているのみであった。

術後経過: 術後バイポーラー+1でマッピングし, 母 音升別能 $55 \%$ ，スピーチトラッキングテスト 7.2 文節 / 分(ともに読唇なし) と通常の経過をたどっていたが, 術 後 3 年頃より音に反応して左顔面㽷攣が生じるようにな った．責任電極は18番の電極であることがわかったので, この電極を使用しないマッピングの変更により顔面痤攣 は治まったが，約 1 週間後より再び顔面痤攣が生じ，18 番に加えて19番の電極で顔面痤變が生じていることがわ からた.

ステンバース耳X線(図 1 ) では, 電極の位置は顔面痤 攣発症前之変化なく, 電極の逸脱等はなかった. 顔面神 経の刺激症状をきたした18番，19番の電極は蝸牛基底回 転の後上方部に位置していることがわかった，側頭骨 ターゲット CT (図 2 ) では蝸牛内の当該電極と顔面神経 迷路部が非常に近接した像が得られた。

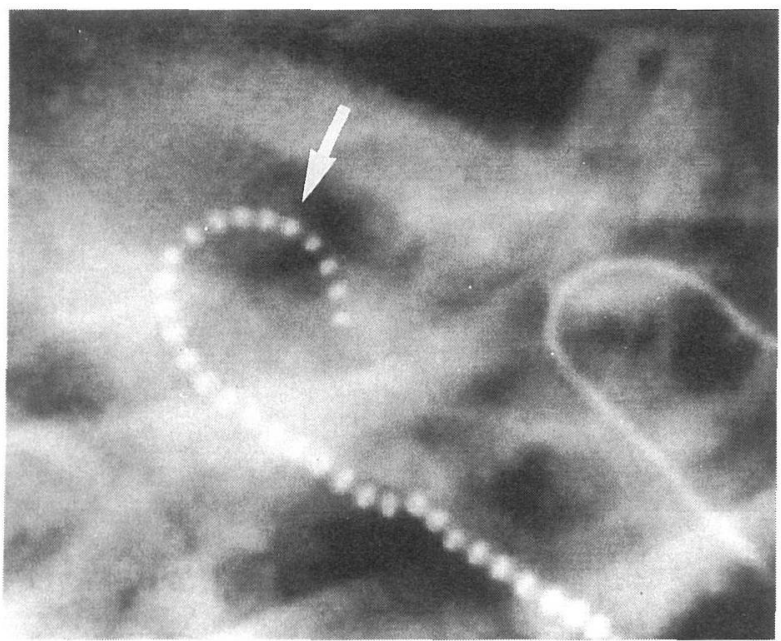

A

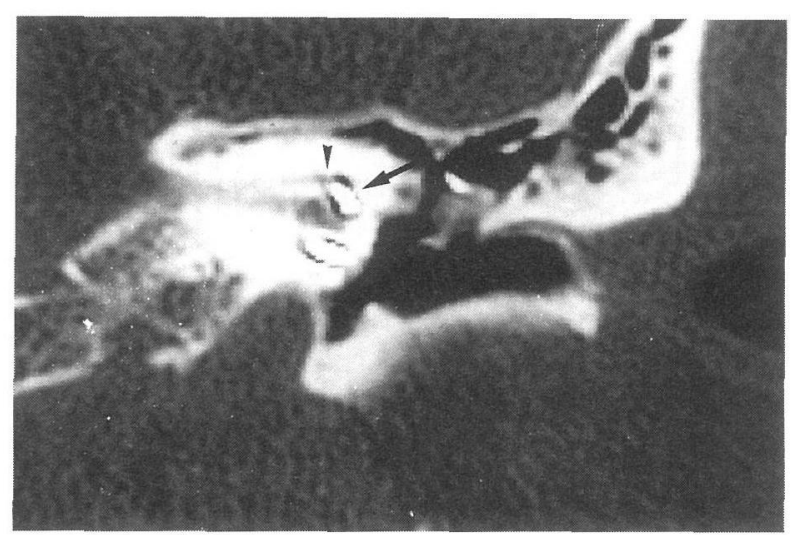

図 2 顔面痓卛発症後の側頭骨ターゲット CT (冠状断) 蝸牛内の電極 (矢印) と顔面神経迷路部 (矢頭)は, 非常に 近接している.

その後17番, 20 番の電極でも顔面症變が生じただめ, これらの電極使用しない上らにマッピングを变更し顔 面痤卛老防いたシ。その後顔面㽷攣の進行は認められない。 顔面痓戀を生ずる電極を他の部分に割り振るマッピング の変更により，母音弁別能は $55 \%$ ，スピーチトラッキン グテストは 8 文節/分（ともに読唇なし）であり，共に悪 化は認められていない。

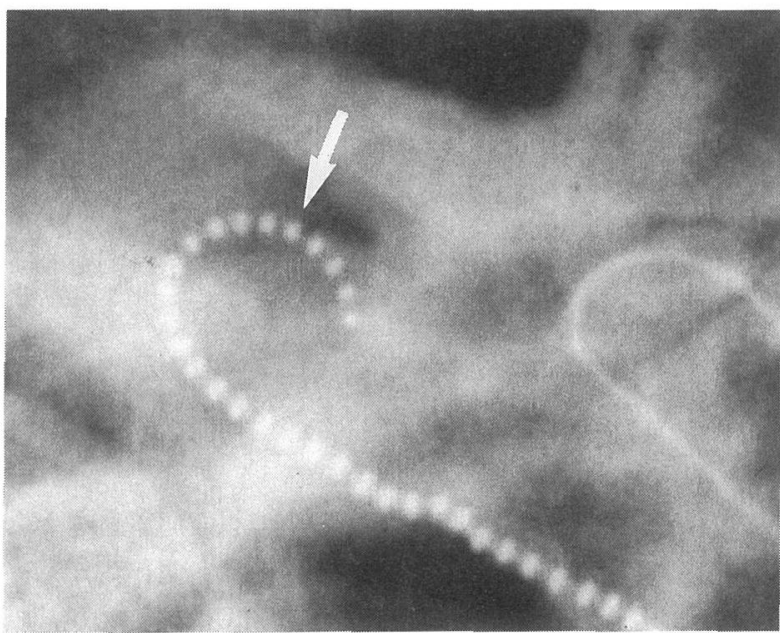

B

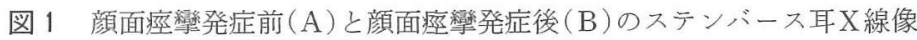

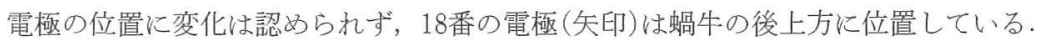




\section{考察}

人工内耳埋め込久術後に生じる顔面㾠攣は, 蝸牛外の 電極に上る顔面神経乳突部の刺激に上るもの之, 蝸牛内 の電極による顔面神経迷路部の刺激によるものがある31. 蝸牛外電極に上る顔面神経乳突部の刺激の場合は, 電極 を蝸牛内に深く挿入することで予防できる3). 一方, 蝸 牛内電極に上る顔面神経刺激に関しては, 図 3 の側頭骨 標本に示す上らに正常人に执いても顔面神経迷路部が蝸 牛基底回転の後上方と極めて近接しているだめ, その部 分で電極が顔面神経を刺激する可能性がある6). 本例で は蝸牛内の電極が顔面神経迷路部を刺激したと考劣られ る.

人工内耳術後の顔面痤攣に関し, Muckle ら²) はその 4 例中 3 例 $(75 \%)$, Weber ら ${ }^{4)}$ は 17 例中 11 例 $(65 \%)$ に 耳硬化症を認めたと報告している. Muckle ら²) は，こ れらの全例で蝸牛基底回転後上方に位置する電極で顔面 疘攣が生じたことから，耳硬化症でこの部の蝸牛骨包の 構造が失われ顔面神経と人工内耳電極との間の電気抵抗 が減少して顔面㽷變が生じた可能性を述べている。本例 では，CT でダブルリングサイン等の広範な蝸牛骨包の 病変は認めないものの, 術中扝よび CT 所見で耳硬化症 が確認された。耳硬化症では骨の脱灰と再化骨が認めら

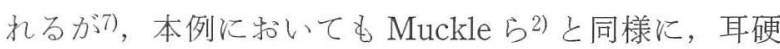
化症に上る脱灰のために顔面神経と蝸牛基底回転後上部 の人工内耳電極との間の電気抵抗が低下し，この部分で 人工内耳電極からの漏洩電流により顔面神経が刺激され て顔面㾏攣が生じたものと推測された。

また，本例では術後 3 年経過して顔面㾏卛をきたした が，Weber ら ${ }^{4)}$ も同様の症例を報告している。これは 耳硬化症が徐々に進行し, 術後 3 年経過して顔面㾤攣が 生じたものと考光られる。またその後も病変が進行した ため, 顔面神経を刺激する電極数が徐々に増加したもの と考光られる. しかし螖牛に近接する顔面神経迷路部之 蝸牛の基底回転の走行は洼㜔直しているため(図 3 ), その近接部は短く, 顔面神経を刺激する電極数が無際限 に多くなるとは考光にくい、本例でも顔面神経を刺激す る電極はその後は増加せず，語音弁別能を悪化させるこ となく対応できている.

耳硬化症をともなら患者に対する人工内耳埋め込久術 については, 従来蝸牛の閉塞による電極の挿入が問題と なっていたが，近年は術後の遅発性顔面痤攣が報告され ている224)，我が国では欧米に比べ耳硬化症例が少ない

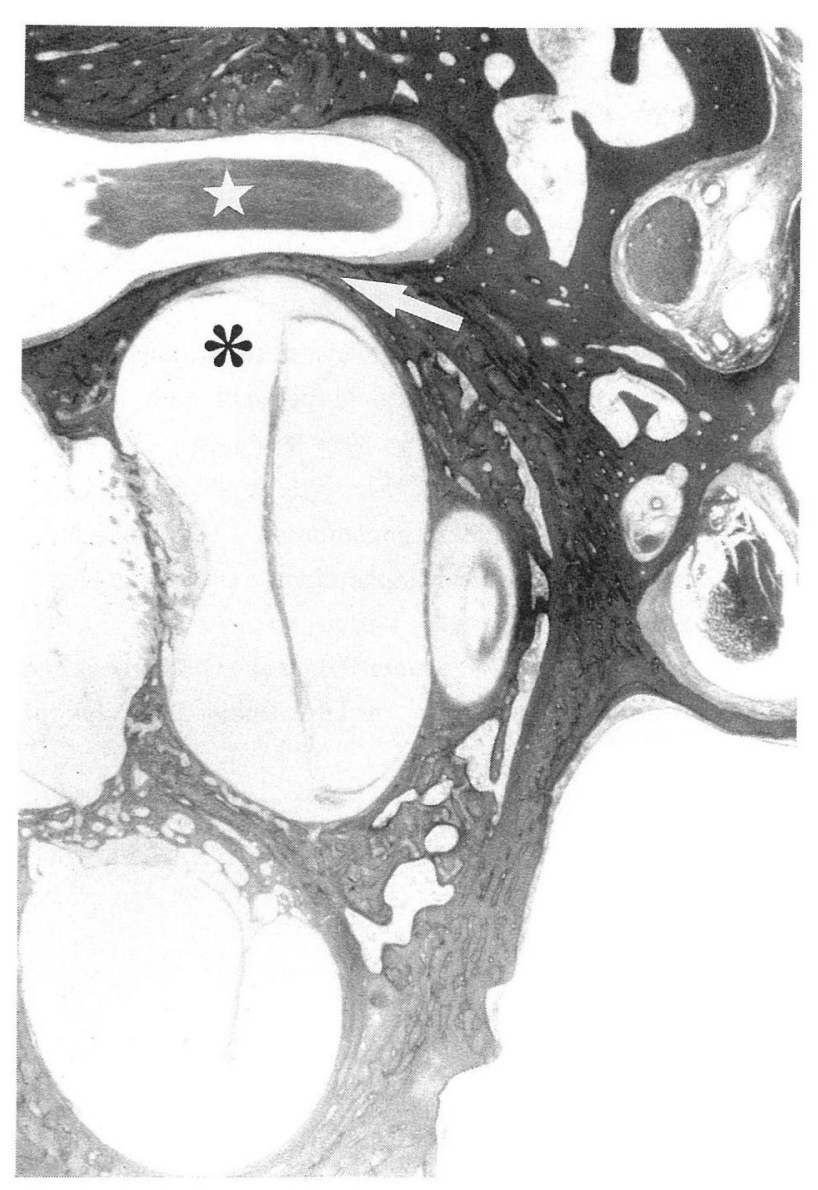

図 3 正常人の側頭骨の冠状断の組織標本

蝸牛の基底回転 $(*)$ と顔面神経迷路部 ( 印)はきわめて薄い。

こともあり, 人工内耳術後の顔面症攣はあまり注目され ていないが，耳硬化症の漸増8) とともに類似症例が出現 する可能性は高い。耳硬化症による感音性難聴例に対し ても人工内耳手術は適応とされることが多く, CT 等で これらに充分留意し, また経過を観察する必要があると 思われる。

$$
\text { まとめ }
$$

耳硬化症をともなら高度感音性難聴に対する人工内耳 術後に 3 年を経過して顔面痤攣をきたした症例を報告し た.

耳硬化症の患者に対する人工内耳埋め込久術では, 蝸 牛骨包の脱灰に上り蝸牛内の電極が顔面神経迷路部を刺 激する可能性があり, 術後に遅発性の顔面痤﨔が生じる 
可能性があることを念頭に扔くべきである.

\section{参考文献}

1) Cohen NL, Hoffman RA and Stroschein M : Medical or surgical complications related to the Nucleus multichannel cochlear implant. Ann Otol Rhinol Laryngol 97 Suppl $135: 8 \sim 13,1988$.

2) Muckle RP and Levine SC : Facial nerve stimulation produced by cochlear implants in patients with cochlear otosclerosis. Am J Otol $15:$ 394 398, 1994.

3 ) Niparko J, Oviatt DL, Coker NJ, et al : Facial nerve stimulation with cochlear implantation. VA Cooperative Study Group on Cochlear Implantation. Otolaryngol Head Neck Surg $104: 826 \sim 830,1991$.

4) Weber BP, Lenarz T, Battmer RD, et al : Otosclerosis and facial nerve stimulation. Am Otol Rhinol Laryngol 104
Suppl $166:$ 445 447, 1995.

5) Valvassori GE and Buckingham RA : Otosclerosis and bone dystrophies. Imaging of the Head and Neck (ed by Valvassori GE, Mafee MF and Carter BL). pp 143 156, Georg Thieme Verlag Stuttgart, New York, 1995.

6 ) 高橋晴雄 : 術後の問題点. 人工内耳(本庄 嚴編). 103 110頁, 中山書店, 東京, 1994.

7 ) Schuknecht HF : Otosclerosis. Pathology of the Ear. pp 365 379, Lea \& Febiger, Philadelphia, 1993.

8 ) 三浦 誠, 高橋晴雄, 内藤 泰, 他: 耳硬化症の最近の動 向と診断・治療. 耳鼻臨床 $88: 575 \sim 579,1995$.

$\left(\begin{array}{l}\text { 原稿受付: 平成 } 8 \text { 年 } 7 \text { 月 } 9 \text { 日 } \\ \text { 原稿採択 : 平成 } 8 \text { 年 } 8 \text { 月 } 14 \text { 日 } \\ \text { 別刷請求先 : 平海晴一 } \\ \text { ₹ } 660 \text { 尼崎市東大物町 } 1-1-1 \\ \text { 兵庫県立尼崎病院耳鼻咽喉科 }\end{array}\right)$ 